Kolaborasi: Jurnal Administrasi Publik, Desember 2018 Volume 4 Nomor 3

\title{
PERAN PEMERINTAH DESA DALAM PENGEMBANGAN BADAN USAHA MILIK DESA DI DESA PATANI KECAMATAN MAPPKASUNGGU KABUPATEN TAKALAR
}

\author{
Fifianti 1, Alyas 2, Ansyari Mone ${ }^{3}$ \\ 1) Jurusan Ilmu Administrasi Negara Unismuh Makassar \\ 2) Jurusan Ilmu Administrasi Negara Unismuh Makassar \\ 3) Jurusan Ilmu Administrasi Negara Unismuh Makassar
}

\begin{abstract}
This study aims to obtain an overview of the role of the village government in relation to empowerment, namely village-owned enterprises (BUMDes) that must be empowered in an effort to strengthen the village economy in Patani Village. This type of research is qualitative and the data analysis used is Phenomenology with the number of informants as many as 11 people. Data collection techniques are observation, documentation, and interviews. The results of this study indicate that BUMDes in Patani Village have not been effective in helping the independence of Patani Village. Because the role of the Government in the guidance and direction of the BUMDes managers is less than optimal. BUMDes managers are less creative in developing existing funds, even though Patani Village has potential that can be developed, such as managing Bricks and Buying and Selling Goats. There is no Transparency and lack of communication between Supervisors, Managers and Members of BUMDes even to the Community, BUMDes Community Management is not directed. Likewise with the community, there are those who understand and know BUMDes and there are those who cannot and do not know at all, even though there are those who can accept BUMDes.
\end{abstract}

Keywords: role of the village government, development and empowermant of BUMDES

\begin{abstract}
ABSTRAK
Penelitian ini bertujuan untuk memperoleh gambaran mengenai Peran Pemerintah Desa dalam kaitannya dengan pemberdayaan yaitu Badan Usaha Milik Desa (BUMDes) yang harus diberdayakan dalam upaya memperkuat perekonomian Desa di Desa Patani. Jenis penelitian ini adalah kualitatif dan analisis data yang digunakan adalah Fenomenologi dengan jumlah informan sebanyak 11 orang. Teknik pengumpulan data yaitu observasi, dokumentasi, dan wawancara. Hasil Penelitian ini menunjukkan bahwa BUMDes yang ada di Desa Patani belum efektif untuk membantu kemandirian Desa Patani. Karena Peran Pemerintah Desa dalam membimbing dan mengawasi para pengelola BUMDes kurang optimal. Pengelola BUMDes kurang kreatif dalam mengembangkan dana yang ada, padahal Desa Patani mempunyai potensi yang bisa dikembangkan, seperti pengelolaan Batu Bata dan Jual-Beli Kambing. Tidak adanya Transparansi dan kurangnya komunikasi antara Pengawas, Pengelola, dan Anggota BUMDes bahkan kepada Masyarakat, sehingga Pengelolaan BUMDes tidak terarah. begitupun dengan masyarakat, ada yang mengerti dan mengetahui BUMDes dan ada yang tidak mengerti dan tidak mengetahui sama sekali, walaupun sebenarnya merekalah yang seharusnya bisa menerima BUMDes.
\end{abstract}

Kata Kunci: Peran Pemerintah Desa, Pengembangan, dan Pemberdayaan BUMDES 


\section{PENDAHULUAN}

Konsep otonomi daerah merupakan salah satu upaya untuk menata ulang sistim struktur dalam masyarakat terutama ketimpangan yang ada antara hubungan pemerintah pusat dengan daerah yang bersifat sentralistik. Sentralisasi kekuatan ekonomi pada kota-kota besar mengakibatkan terjadinya laju urbanisasi dan sekaligus menciptakan jurang yang besar antara kemajuan kota dan kemisikinan masyarakat pedesaan. Padahal secara faktual, eksistensi desa sebagai poros utama pertanian justru harus semakin dimaksimalkan.

Badan Usaha Milik Desa (BUMDes) sebagai bayi yang baru lahir butuh sentuhan, butuh pembinaan, butuh pengawasan, jangan sampai Badan Usaha Milik Desa (BUMDes) hanya menjadi sebuah Project atau kegiatan tahunan yang 1 tahun habis, tahun depannya tidak dianggarkan sehingga akan mati dengan sendirinya. Kementrian Desa harus memikirkan langkah-langkah bagaimana menjadikan Badan Usaha Milik Desa (BUMDes) ini sebagai Usaha Desa yang harus berjalan dan produktif bermanfaat dan mandiri walaupun berganti menteri dan Presiden. Badan Usaha Milik Desa (BUMDes) adalah milik desa, bukan kementerian desa, kemajuan dan keberhasilan Badan Usaha Milik Desa (BUMDes) tergantung dari Desa sendiri.

Kondisi ideal yang diharapkan terjadi dari Badan Usaha Milik Desa (BUMDes) bukan hanya sebagai bentuk lembaga sosial saja tapi menjadi lembaga ekonomi yang bisa memenuhi kebutuhan masyarakat dan anggota. Peranan-peranan pemberdayaan ditujukan untuk mensejahterakan masyarakat khususnya masyarakat menengah kebawah yang memerlukan bantuan modal usaha agar bisa memiliki usaha sendiri dengan begitu mereka bisa meningkatkan taraf hidup dan kesejahteraan hidupnya. Peran pengurus Badan Usaha Milik Desa (BUMDes) memberikan pemberdayaan kepada seluruh anggotanya mulai dari tahapan persiapan, tahapan (penilaian), tahapan perencanaan alternatif program/kegiatan, tahapan pemformulasian program, tahapan pelaksanaan, tahap evaluasi dan tahap terminasi. Pada tahapan-tahapan tersebut masyarakat dilibatkan secara langsung yaitu supaya masyarakat mengerti akan masalah yang dihadapi serta dapat 
mengentaskan permasalahan mereka sendiri sampai mereka mandiri.

Selanjutnya dalam program perberdayaan Badan Usaha Milik Desa (BUMDes) membentuk program bersama dengan para anggotanya, dalam hal ini pengurus, anggota dan masyarakat sudah berperan aktif dalam seluruh kegiatan pemberdayaan tersebut serta dapat memberikan solusi dan masukan bagi keperluan/ kebutuhan mereka sendiri.

Akan tetapi dalam pelaksanaanya kadang tidak sesuai dengan teori, sebagaimana dinyatakan dalam Peraturan Menteri Desa, Pembangunan Daerah Tertinggal, dan Transmigrasi Nomor 4 Tahun 2015 tentang Pendirian, Pengurusan dan Pengelolaan, dan Pembubaran Badan Usaha Milik Desa. Oleh karena itu, setiap Pemerintah Desa dapat mendirikan Badan Usaha Milik Desa (BUMDes). Pendirian BUMDes dilandasi oleh Peraturan Daerah Kabupaten Takalar Nomor 05 Tahun 2015 tentang Badan Usaha Milik Desa.

Pembagian Dana Badan Usaha Milik Desa (BUMDes) kemasyarakat didesa Patani Kec. Mappakasunggu dalam bentuk simpan pinjam yang tidak tepat sasaran karna sebagian besar yang mendapatkan dana tersebut adalah orang yang tidak mempunyai kegiatan usaha baik itu kecil maupun besar. Seperti misalnya penjual barang campuran/warung, Penjual pakaian atau toko-toko kue yang di anggap bisa mengembangkan usahanya melalui Dana Badan Usaha Milik Desa (BUMDes) tersebut tanpa membutuhkan uang rentenir. Inilah yang menyebabkan ekonomi masyarakat di Desa Patani tidak ada peningkatan. padahal ada beberapa kegiatan usaha yang bisa di danai oleh Badan Usaha Milik Desa (BUMDes), antara lain usaha pembuatan Batu Bata/ Batu Merah, usaha Peternakan dan Jual Beli Kambing, kedua Bidang Usaha tersebut sangat potensi untuk dikembangkan di Desa Patani.

Pemerintahan Desa adalah penyelenggaraan urusan Pemerintahan oleh Pemerintah Desa dan Badan Permusyawaratan Desa dalam mengatur dan mengurus kepentingan masyarakat setempat berdasarkan asal-usul dan adatistiadat setempat yang di akui dan dihormati dalam sistem pemerintahan Negara Kesatuan Republik Indonesia (PP No 72 Th 2005 Pasal 1.6). Pemerintah Desa merupakan struktur Pemerintahan 
Negara yang paling dekat dengan masyarakat, sebagai penyambung pemerintahan pusat di desa yang bertindak sebagai Pembina, pengayom, dan pelayanan masyarakat. Pemerintah Desa adalah Kepala Desa dan perangkat desa sebagai unsur penyelenggara pemerintah desa. Peran Pemerintah sebagai regulator adalah menyiapkan arah untuk menyeimbangkan penyelenggaraan pembangunan melalui penerbitan peraturan-peraturan. Sebagai regulator, pemerintah memberikan acuan dasar kepada masyarakat sebagai instrumen untuk mengatur segala kegiatan pelaksanaan pemberdayaan menurut Ryaas Rasyid dalam Muhadam Lobolo (2010: $32)$.

Peran Pemerintah sebagai dinamisator adalah menggerakkan partisipasi masyarakat jika terjadi kendalakendala dalam proses pembangunan untuk mendorong dan memelihara dinamika pembangunan daerah. Pemerintah berperan melalui pemberian bimbingan dan pengarahan secara intensif dan efektif kepada masyarakat. Biasanya pemberian bimbingan diwujudkan melalui tim penyuluh maupun badan tertentu untuk memberikan pelatihan. Selain apa yang dikemukakan oleh Ryaas Rasyid dalam Muhadam Lobolo (2010: 32) tersebut juga telah ada teori terdahulu dikemukakan oleh Pitana dan Gayatri (2005: 95) dalam pilar good governance, agar dapat berlangsung pembangunan yang ideal, maka pemerintah, swasta dan masyarakat harus dapat bersinergi dengan baik.

$$
\text { Badan Usaha Milik Desa (BUMDes) }
$$
adalah lembaga usaha desa yang dikelola oleh masyarakat dan pemerintahan desa dalam upaya memperkuat perekonomian desa dan dibentuk berdasarkan kebutuhan dan potensi desa. BUMDes menurut Peraturan Menteri Desa, Pembangunan Daerah Tertinggal, dan Transmigrasi Nomor 4 Tahun 2015 tentang Pendirian, Pengurusan dan Pengelolaan, dan Pembubaran Badan Usaha Milik Desa. dan di perkuat oleh Peraturan Daerah Kabupaten Takalar Nomor 05 Tahun 2015 tentang Badan Usaha Milik Desa, didirikan antara lain dalam rangka meningkatkan perekonomian Desa. Berangkat dari cara pandang ini, jika pendapatan asli desa dapat diperoleh dari BUMDes, maka kondisi itu akan mendorong setiap Pemerintah Desa memberikan "goodwill” 
dalam merespon pendirian BUMDes mampu memberikan kontribusi yang signifikan terhadap peningkatan kesejahteraan warga desa. disamping itu, supaya tidak berkembang sistem usaha kapitalistis di pedesaan yang dapat mengakibatkan terganggunya nilai-nilai kehidupan bermasyarakat.

Menurut Sekaran dalam Novita (2013: 75) Kerangka Konseptual dalam penelitian kualitatif adalah penuangan hasil tangkapan peneliti atas fenomena sosial yang diamati serta model konseptual tentang bagaimana teori berhubungan dengan berbagai faktor yang telah didefinisikan sebagai masalah penting.

Peran Pemerintah Desa Dalam Pengembangan Badan Usaha Milik Desa (BUMDes) di Desa Patani Kecamatan Mappakasunggu Kabupaten Takalar adalah untuk mensejahterakan masyarakat dalam meningkatkan perekonomian desa. Berdasarkan rumusan masalah yang telah dikemukakan dalam penelitian ini, maka peneliti memberikan gambaran dengan judul dan teori yang telah dibahas. Untuk menentukan dan mengetahui bagaiman Peran Pemerintah Desa Dalam Pengembangan Badan Usaha Milik Desa
(BUMDes) di Desa Patani Kecamatan Mappakasunggu Kabupaten Takalar digunakan 3 (tiga) Indikator untuk menilai hal tersebut, yaitu sebagai Regulator, sebagai Dinamisator, sebagai Fasilitator. untuk mewujudkan pengelolaan BUMDes yang baik sehingga mencapai keberhasilan yang diharapkan agar BUMDes berkembang.

\section{METODE PENELITIAN}

Penelitian ini berlokasi pada kantor Desa Patani di Kabupaten Takalar Mengenai Peran Pemerintah Desa dalam Pengembangan Badan Usaha Milik Desa (BUMDes) penelitian ini berlangsung dalam kurung waktu 2 bulan. Alasan memilih lokasi tersebut didasar pada adanya 2 (dua) Potensi Desa yang perlu dikembangkan melalui dana BUMDes yaitu Jual-Beli Kambing dan Usaha BatuBata (Batu Merah).

Jenis penelitian ini adalah Kualitatif dimaksudkan untuk memberi pemahaman kepada masyarakat mengenai peran pemerintah desa dalam Pengembangan Badan Usaha Milik Desa (BUMDes). Sugiyono (2015: 7), metode kualitatif juga disebut metode artistic, karna proses 
peneltian lebih bersifat seni (kurang terpola) dan di sebut sebagai metode interpretive karna data hasil penelitian lebih berkenaan dengan interpretasinya terhadap data yang ditemukan pada saat turun langsung di lapangan. Tipe Penelitian ini adalah Fenomenologi dimaksudkan untuk memberi pemahaman secara jelas mengenai masalah yang diteliti sehubungan dengan Peran Pemerintah dalam Pengembangan Badan Usaha Milik Desa (BUMDes).

Data primer adalah data yang diperoleh langsung dari para informan di Kantor Desa Patani Kecamatan Mappakasunggu Kabupaten Takalar dan hasil wawancara dan observasi atau pengamatan langsung terhadap objek yang diteliti. Terkait peran pemerintah desa dalam Pengembangan Badan Usaha Milik Desa (BUMDes). Data sekunder adalah data yang diperoleh peneliti dari bahan bacaan atau dokumentasi yang berhubungan dengan objek peneliti. Seperti pencatatan dokumen-dokumen atau arsip, fungsi dan tugas seksi terkait, sarana dan prasarana kerja, dan lain-lain.

\section{HASIL DAN PEMBAHASAN}

Kantor Desa Patani Kecamatan Mappaasunggu Kabupaten Takalar berada dalam lingkup wilayah Kecamatan Mappakasunggu Kabupaten Takalar di Jl. Proros Mangulabbe Kabupaten Takalar yang letaknya sangat strategis karna dekat dengan Ibu Kota Kabupaten Takalar dengan jarak tempuh sekitar 1 Km.yang terdiri dari lima (5) Dusun yakni Dusun Patani, Dusun Pattekerang, Dusun Mangulabbe, Dusun Bontomanai, dan Dusun Bontolanra Secara umum keadaan topografi Desa Patani adalah dataran rendah dan datar, yang sebagian besar masyarakat bermata pencaharian sebagai petani, jual beli kambing, dan sebagai pembuat Batu Bata.

Visi adalah suatu gambaran yang menantang tentang keadaan masa depan yang di inginkan dengan potensi dan kubutuhan Desa, penyusunan Visi Desa Patani ini di lakukan dengan pendekatan partisipatif, dengan melibatkan semua steakholder dan dengan pertimbangan eksternal Desa, maka berdasarkan hal tersebut diatas Visi Desa Patani adalah “Mewujudkan Desa Patani Menjadi Desa 
Mandiri Melalui Bidang Pertanian dan Industri Rumah Tangga”

Berdasarkan Visi pembangunan Desa tersebut ditetapkan 8 (Delapan) Misi Pembangunan Desa Patani Tahun 20142018 sebagai berikut yaitu memperbaiki dan menambah sarana dan prasarana yang dibutuhkan untuk meningkatkan SDM melalui pendidikan formal dan informal, memperbaiki infrastruktur yang bisa menunjang kegiatan produksi pertanian, membangun tata ruang wilayah Desa Patani dalam membangun Desa Mandiri, bekerjasama dengan penyuluh pertanian untuk meningkatkan hasil pertanian, meningkatkan pendapatan masyarakat melalui sektor pengembangan ekonomi rumah tangga (Home Industri), meningkatkan pendapatan masyarakat melalui perbaikan prasarana pertanian dan alat-alat produksi pertanian, mengutamakan persamaan hak antara lakilaki dan perempuan dalam mengisi keanggotaan lembaga-lembaga yang ada di Desa.

Organisasi ekonomi pedesaan menjadi bagian penting dalam suatu desa, namun sekaligus masih menjadi suatu titik lemah dalam rangka mendukung penguatan ekonomi pedesaan. Oleh karena itu di perlukan usaha yang sistemasis untuk mendorong organisasi ini agar dapat mengelola aset ekonomi demi daya saing yang meningkat di pedesaan. Dalam konteks demikian, BUMDes Patani pada dasarnya merupakan bentuk penguatan terhadap lembaga-lembaga ekonomi di desa patani. BUMDes Patani merupakan instrument pemberdayaan masyarakat tentang potensi ekonomi lokal dengan beragam jenis potensi. Penggunaan sumber daya ekonomi atau potensi ini terutama bertujuan untuk peningkatan kesejahteraan ekonomi warga desa melalui pengembangan usaha ekonomi mereka. Disamping itu, keberadaan BUMDes Patani juga memberikan sumbangsinya dalam meningkatkan pendapatan asli desa yang memungkinkan desa mampu melaksanakan pembangunan dan peningkatan kesejahteraan rakyat secara optimal.

Mempunyai tugas melaksanakan dan memberikan nasehat kepada pelaksana operasional atau direksi dalam menjalankan kegiatan pengelolaan usaha desa. Penasehat dalam melaksanakan tugas mempunyai kewenangan meminta 
penjelasan pelaksanaan operasional atau direksi mengenai pengelolaan usaha desa.

Mempunyai tugas mengawasi semua kegiatan dan kinerja pelaksana operasional atau direksi dalam menjalankan kegiatan pengelolaan usaha desa. Pengawas dalam melaksanakan tugas mempunyai kewenangan sebagai berikut yaitu meminta Laporan Pertanggung Jawaban pelaksana operasional setiap akhir tahun, meminta laporan kegiatan unit-unit usaha milik desa, meminta laporan rincian neraca rugi laba dan penjelasan-penjelasan atas dokumen kegiatan unit-unit usaha pengangkatan dan pemberhentian pengurus/pelaksana operasional mewujudkan pemerintahan yang baik dan bersih melalui pelaksanaan otonomi daerah.

Peran pemerintah desa dalam mengelola BUMDes yaitu mendirikan, berpartisipasi dalam mengendalikan program kerja yang diselenggarakan BUMDes untuk pengembangan dan pemberdayaan masyarakat di Desa Patani seperti pemberian pinjaman modal usaha. Keterlibatan perangkat desa dalam pengelolaan BUMDes adanya pengawasan, pengontrolan dan evaluasi dari program BUMDes. Perangkat desa menjalankan tugas, fungsi, wewenang dan tanggung jawab untuk mengurus dan menjalankan kehendak masyarakat terutama dalam mengembangkan BUMDes.

Dalam implementasi BUMDes maka terdapat beberapa permasalahan yang dialami oleh pemerintah desa dalam pengembangan BUMDes, seperti keterlambatan pencairan dana yang digunakan dalam pengembangan BUMDes. Sehingga pengembangan BUMDes dirasakan lamban dan masyarakat kurang berpartisipasi dalam memelihara BUMDes yang sudah ada, tetapi masalah yang dihadapi pemerintah desa tidak sebagai patokan dalam penyelengaraan kegiatan di desa Patani karena dapat di komunikasikan antar pemerintah Desa dan Bumdes, karena BUMDes bertujuan memberdayakan dan mensejahterakan masyarakat, sehingga terdapat tiga poin peran pemerintah Desa Patani dalam mengelola BUMDes yaitu sebagai regulator, sebagai dinamisator, sebagai faslitator.

Regulator adalah menyiapkan arah untuk menyeimbangkan penyelenggaraan 
pembangunan melalui penerbitan peraturan-peraturan. Sebagai regulator, pemerintah desa memberikan acuan dasar kepada masyarakat sebagai instrumen untuk mengatur segala kegiatan Pelaksanaan Pemberdayaan.

Berdasarkan hasil Observasi selama di lapangan peneliti menemukan hal yang berbeda, BUMDes berdiri pada tahun 2014 dan dari beberapa kegiatan BUMDes adalah yang termasuk simpan Pinjam. Tapi kenyataan yang terjadi di lapangan ada beberapa informasi yang berbeda-beda. Ada yang mengatakan BUMDes berdiri tahun 2015 dan dananya baru terealisasi pada tahun 2017, dan hanya simpan pinjam yang berjalan efektif namun tidak tepat sasaran.

Berdasarkan hasil observasi peneliti bahwa dalam pengawasan pengelolaan laporan kegiatan tidak adanya transparansi antara pemerintah desa ke Badan Pengawas Desa (BPD), sehingga pengelolaan BUMDes tersebut tidak Efektif dan tidak berjalan sesuai dengan aturan. Berdasarkan hasil observasi yang dilakukan oleh peneliti dilapangan bahwa, terbukti di lapangan sebagai direktur BUMDes dalam melaksanakan kebijakan terkadang tidak sesuai dengan aturan dan tujuan BUMDes, begitupun dalam mengkoordinir pelaksanaan kegiatan unit usaha tentang laporan kegiatan, laporan keuangan, dan pembagian dana BUMDes yang tidak terkoordinir dengan baik sehingga pengelolaan BUMDes ini tidak sesuai tujuan BUMDes.

Direktur BUMDes memberikan aturan yang tidak sesuai dengan tujuan BUMDes yang sebenarnya dalam hal tentang syarat memberi bantuan modal. yang mempunyai unit usaha contohnya toko/warung yang di berikan modal sehingga walaupun masyarakat itu dalam segi ekonomi tidak masuk kategori miskin tapi tetap mendapatkan dana karna tetap mempunyai usaha, sehingga walaupun masyarakat itu miskin tapi tidak mempunyai jenis usaha maka tidak memenuhi syarat untuk mendapatkan dana BUMDes, inilah yang menjadi permasalahan tentang bantuan dana BUMDes justru tidak sesuai dengan tujuan BUMDes untuk mensejahterakan msyarakat dalam meningkatkan ekonomi masyarakat miskin.

Berdasarkan hasil observasi dilapangan, bahwa memang benar 
pengurus BUMDes memberikan dana 1 juta perorang dalam bentuk simpan pinjam, dalam bentuk iuran simpan pinjam itu merasa berat bagi masyarakat, karna dana yang diterima tidak sebanding dengan iuran yang dibayarkan, sehingga inilah yang menjadi salah satu masalah bagi masyarakat yang menerima dana BUMDes.

Mengenai iuran perbulan itu tidak menentu dan belum menetapkan aturan pembayaran sehingga masyarakat tidak di berikan sanksi dan seenaknya tidak membayar iuran perbulan, yang mengakibatkan tidak berkembangnya modal sehingga cenderung lambat dalam pembagian modal(yang belum mendapatkan). Warga ini sudah tau ada BUMDes, dan sudah memasukkan proposal dengan tujuan ingin juga mendapatkan bantuan dana BUMDes, akan tetapi pengurus BUMDes sampai sekarang tidak memberikan bantuan dana BUMDes padahal setelah melakukan observasi dilapangan terbukti warga ini memenuhi syarat untuk mendapatkan bantuan dana BUMDes.

Salah seorang mendapatkan dana BUMDes karna aturan di pengurus
BUMDes layak sebab memiliki usaha sendiri, akan tetapi setelah di observasi di lapangan terbukti warga ini sebenarnya tidak layak dan tidak memenuhi syarat kategori penerima bantuan dana BUMDes, setelah di telusuri lebih dalam warga ini mempunyai hubungan keluarga dengan salah satu Staf di Desa Patani yang kebetulan Pemerintah Desa Patani yang menangani BUMDes tersebut. disinilah salah satu bukti adanya penyimpangan dalam pembagian, akibatnya BUMDes ini tidak tepat sasaran.

Salah seorang warga mendapatkan dana BUMDes, padahal tidak layak mendapatkan bantuan, karna tidak memenuhi syarat dan juga warga ini mempunyai ekonomi lumayan baik, dan setelah di wawancarai lebih mendalam warga ini bertetangga dengan sekretaris BUMDes, dan pengurus BUMDes mengatakan boleh dapat walaupun tidak ada usaha yang penting bisa membayar iuran, inilah salah satu permasalahan di BUMDes mereka memberikan bantuan tanpa mengerti dan memahami dengan baik apa tujuan BUMDes yang sebenarnya. Yang seharusnya warga ini tidak dapat karna tidak punya usaha dan 
ekonominya juga baik tapi tetap mendapatkan bantuan karna lagi-lagi adanya nepotisme didalam pembagian tersebut.

Salah seorang warga mendapatkan bantuan dana BUMDes dan layak mendapatkan bantuan karna memenuhi syarat. yang sebenarnya, dan setelah di observasi lebih jauh ternyata warga ini sebelumnya sudah pernah masuk anggota PNPM sehingga warga ini tanpa didata pun sebenarnya sudah mendapatkan bantuan dana BUMDes.

Salah seorang warga tidak mendapatkan dana bantuan dana BUMDes setelah data oleh pengurus BUMDes karna tidak memenuhi syarat kategori penerima bantuan dana BUMDes walaupun warga ini di kategorikan warga miskin. Dan setelah ditelusuri lebih jauh ternyata warga ini tidak mempunyai usaha tapi masuk kategori miskin, dan seharusnya ini layak mendapatkan bantuan modal untuk bisa memulai usaha baru sehingga warga ini mempunyai peningkatan melalui usaha yang di miliki.

Dinamisator adalah menggerakkan partisipasi masyarakat jika terjadi kendalakendala dalam proses pembangunan untuk mendorong dan memelihara dinamika pembangunan daerah. Pemerintah berperan melalui, pemberian bimbingan. Memberi bimbingan bagi pengurus BUMDes untuk Pengelolaan BUMDes, dengan harapan semoga dapat dikelola dengan baik dan dapat dimanfaatkan dengan sebaik-baiknya serta meningkatkan minat masyarakat untuk mendapatkan dana BUMDes.

Berdasarkan hasil observasi di lapangan peneliti menemukan bahwa dari segi pemberian bimbingan bagi pengurus BUMDes tidak terlalu intensif dalam artian pemerintah kurang memberikan bimbingan langsung baik dari segi pemantauan dan pendampingan khusus karna adanya hambatan kesibukan masingmasing pengurus, minimnya anggaran dan kurangnya kesadaran pemerintah dalam memperhatikan pengelolaan BUMDes, itu terbukti dari perkembangan BUMDes yang cenderung lamban dan tidak efektif.

Berdasarkan hasil penelitian di lapangan pengurus BUMDes kurang mensosialisasikan tentang dana BUMDes kepada masyarakat, terbukti masih banyak masyarakat di desa patani yang tidak mengetahui adanya bantuan dana BUMDes dan juga Direktur BUMDes 
mengatakan bahwa adanya controling terhadap penerima dana bantuan apakah bantuan dana yang di berikan di gunakan dengan baik atau tidak, akan tetapi sebagian masyarakat yang mendapatkan dana itu tidak mempunyai usaha sehingga penyuluhan ataupun controling hanyalah formalitas semata. Inilah yang menjadi salah satu permaslahan dalam pengelolaan BUMDes karna kurangnya bimbingan dan pengawasan Pemerintah.

Berdasarkan hasil penelitian di lapangan ternyata masyarakat masih banyak yang tidak mengetahui atau tidak mengenal tentang bantuan dana BUMDes sehingga kurangnya minat masyarakat, dan juga adanya perjanjian tentang syarat untuk mendapatkan dana yang dirasa berat oleh masyarakat dan tidak sepadan dengan jumlah dana yang di berikan. Salah seorang warga tidak berminat mendapatkan bantuan walaupun masuk kategori miskin dan tidak mempunyai usaha, karna warga tersebut menganggap bantuan dengan dana Rp.1000.000 tidak mencukupi jika memiliki usaha dan katanya harus ada jaminan yang menurutnya merasa berat. Sebenarnya warga ini kurang paham tentang bantuan dana ini, kurang memahami usaha yang bagus dan sedikit bisa membantu ekonominya, sebab pengurus BUMDes kurang melakukan sosialisasi lebih mendalam agar warga ini dapat memahami tujuan BUMDes.

Fasilitator adalah menciptakan kondisi yang kondusif bagi pelaksanaan pembangunan untuk menjembatani berbagai kepentingan masyarakat dalam mengoptimalkan pembangunan daerah. Sebagai fasilitator, pemerintah memberi pendampingan melalui pelatihan, pendidikan, dan peningkatan keterampilan, memberi modal usaha kepada masyarakat yang diberdayakan. Dengan adanya bantuan modal dana BUMDes ini akan meningkatkan pengolahan potensi desa sesuai dengan kebutuhan masyarakat dan pendampingan dalam pengembangan BUMDes. Sehingga menjadi daya dorong (steam engine) dalam upaya pengentasan kemiskinan.

Pemerintah memberikan fasilitas berupa dana kepada pengurus BUMDes untuk di alokasikan kepada masyarakat sebagai dana BUMDes, akan tetapi setelah ditelusuri lebih jauh kepada masyarakat ternyata dana tersebut tidak sebanding 
dengan bantuannya. nyatanya masih juta, dan setelah itu baru bisa di gulirkan. banyak masyarakat yang ingin Akan tetapi setelah di lakukan observasi mendapatkan bantuan modal dari pengurus BUMDes, tapi katanya dana sudah tidak cukup lagi, dan masyarakat yang mendapatkan bantuan dana BUMDes tidak seberapa. Di sinilah salah satu contoh lemahnya peran pemerintah dalam memberikan fasilitas dana kepada masyarakat.

Berdasarkan hasil observasi Bahwa pendamping BUMDes tidak harus mendampingi soal masalah pembagian dana bantuan modal kepada masyarakat, pendamping BUMDes hanya mendampingi kelengkapan administrasi serta membimbing pengurus dalam hal pembukuan keuangan, setelah di telusuri tugas dari pendamping BUMDes seharusnya pendamping BUMDes mendampingi juga dalam hal pembagian dana langsung kepada masyarakat agar adanya transparansi dana antara pengurus dan pendamping sehingga tidak adanya penyimpangan masalah pembagian dana tersebut.

Berdasarkan hasil observasi bahwa pengurus BUMDes hanya bisa memberikan kepada masyarakat sampai 3 dilapangan penulis menemukan adanya masyarakat yang mendapatkan bantuan dana lebih dari 3 kali sehingga tidak adanya perguliran dana untuk masyarakat yang lain yang masih banyak ingin mendapatkan Bantuan dana BUMDes. Permasalahan yang ada di BUMDes sangat jelas terjadi, karna tidak adanya peran pemerintah dalam hal pengawasan kepada pengurus BUMDes, sehingga banyak masyarakat yang tidak merasakan bantuan dari Pemerintah.

Berdasarkan hasil observasi dilapangan bahwa, masyarakat yang mendapatkan dana BUMDes ada juga yang memang betul-betul mempunyai usaha, tapi ada juga yang tidak mempunyai usaha tetap diberikan bantuan dana, sehingga bentuk prioritas pengurus BUMDes dalam hal kategori pembagian dana tidak sesuai dengan hasil observasi di lapangan, adanya pembagian bantuan dana yang tidak tepat sasaran.

\section{PENUTUP}

Berdasarkan hasil peneltian ini, penulis sekaligus sebagai peneliti dapat 
Kolaborasi: Jurnal Administrasi Publik, Desember 2018 Volume 4 Nomor 3

menyimpulkan bahwa BUMDes yang ada di Desa Patani belum efektif untuk membantu kemandirian Desa Patani. Karna Peran Pemerintah Desa dalam membimbing dan mengawasi para Pengelola BUMDes kurang optimal. Pengelola BUMDes kurang kreatif dalam mengembangkan dana yang ada, padahal Desa Patani mempunyai potensi yang bisa dikembangkan, seperti pengelolaan Batu Bata dan Jual-Beli Kambing. Tidak adanya Transparansi dan kurangnya komunikasi antara Pengawas, Pengelola, dan Anggota BUMDes bahkan kepada Masyarakat, sehingga Pengelolaan BUMDes tidak terarah. begitupun dengan masyarakat, ada yang mengerti dan mengetahui BUMDes dan ada yang tidak mengerti dan tidak mengetahui sama sekali, walaupun sebenarnya merekalah yang seharusnya bisa menerima BUMDes.

Berdasarkan Hasil Penelitian yang saya lakukan di Desa Patani Kecamatan Mappakasunggu Kabupaten Takalar tentang Pengelolaan BUMDes, maka saran yang diberikan sebagai Penulis dan Sekaligus sebagai Peneliti yaitu Pemerintah sebagai Pengawas dan Pembimbing sekaligus Penasihat bagi para
Pengurus dan Pengelola BUMDes harusnya lebih giat dan lebih memaksimalkan Bimbingan dan Pengawasannya dengan mengadakan Pertemuan setiap Bulan, Pemerintah Desa diharapkan mengadakan sosialisasi kepada masyarakat untuk melihat dan mengetahui Potensi yang ada dan bisa di kembangkan.

\section{DAFTAR PUSTAKA}

1. Buku

Arwati, Dini, dan Hadiati Novita. 2013. Pengaruh Pertumbuhan Ekonomi, Pendapatan Asli Daerah dan Dana Alokasi Umum Terhadap Pengalokasian Anggaran Belanja Modal pada Pemerintah Daerah Kabupaten/Kota di Propinsi Jawa Barat. Seminar Nasional Teknologii Informasi dan Komunikasi Terapan 2013 (SEMANTIK 2013).

Bauer, Jeffrey C. 2003.Peran Ambiguitas dan Peran Kejelasan: Perbandingan antara Sikap di Jerman dan Amerika Serikat. Disertasi, Universitas Cincinnati - Clermont.

Bungin, Burhan. 2012. Metode Penelitian Kualitatif: Aktualisasi Metodologis ke Arah Ragam Varian Kontemporer. Jakarta: Rajawali Pers.

Bryant, dan. White dalam Amira. 2012. Sosiologi Suatu Pengantar. Jakarta: Rajawali Pers. 
Labolo, Muhadam. 2010. Memahami Ilmu Pemerintahan: Suatu Kajian, Teori, Konsep dan Pembangunan. Jakarta: Rajawali Press.

Nugraha, Rian.2003. Pengantar Kebijakan Publik. Raja Grafindo Persada. Jakarta.

Parsons, Ruth J., James D. Jorgensen dan Santos H. Hernandez. 1994.Integrasi dari Praktek Kerja Sosial, California: Brooks/Cole.

Pitana I Gede \& Putu G. Gayatri. 2005. Sosiologi Pariwisata. Yogyakarta: Penerbit Andi

Riyadi.2002. Perencanaan Pembangunan Daerah strategi Mengendalikan Potensi Dalam Mewujudkan Otonomi Daerah. Jakarta: Gramedia.

Robins, Stephen P. 2001. Perilaku Organisasi: Konsep, Kontroversi, Aplikasi, Jilid 1 Edisi 8 Prenhallindo Jakarta.

Soerjono Soekanto, 2009, Peranan Sosiologi Suatu Pengantar, Edisi Baru, Rajawali Pers, Jakarta, 2015, Sosiologi Suatu Pengantar. Ed. Revisi, Cet. 47. Rajawali Pers, Jakarta.

Sugiyono, 2004, Metode Penelitian Administrasi, Alfabeta, Bandung.

2005, Memahami Penelitian Kualitatif, Alfabeta, Bandung.

2011. Metode Penelitian kuantitatif kualitatif dan $R \& D$, Alfabeta, Bandung.

Wulansari, Dewi. 2009. Sosiologi Konsep dan Teori. Bandung: Refika Aditama.
2. Jurnal

Arwati, Dini, dan Hadiati Novita. 2013. Pengaruh Pertumbuhan Ekonomi, Pendapatan Asli Daerah dan Dana Alokasi Umum Terhadap Pengalokasian Anggaran Belanja Modal pada Pemerintah Daerah Kabupaten/Kota di Propinsi Jawa Barat. Seminar Nasional Teknologii Informasi dan Komunikasi Terapan 2013 (SEMANTIK 2013).

3. Peraturan Pemerintah

Peraturan Menteri Desa, Pembangunan Daerah Tertinggal, dan Transmigrasi Nomor 4 Tahun 2015 tentang Pendirian, Pengurusan dan Pengelolaan, dan Pembubaran Badan Usaha Milik Desa.

Peraturan Daerah Kabupaten Takalar Nomor 05 Tahun 2015 tentang Badan Usaha Milik Desa.

System Pemerintahan Negara Kesatuan Republik Indonesia (PP No 72 Tahun 2005 Pasal 1.6) tentang Pemerintahan Desa.

Undang-undang Pemerintah daerah No. 32 Tahun 2004 Pasal 202 Tentang Pemerintah Desa 